NIKOLINA BRNJAC, Ph.D.

Intermodal Transport

E-mail: brnjac@fpz.hr

IVANA ĆAVAR, B.Eng.

Review

E-mail: ivana.cavar@fpz.hr

Accepted: Apr. 21, 2009

University of Zagreb,

Faculty of Transport and Traffic Sciences

Vukelićeva 4, HR-10000 Zagreb, Republic of Croatia

\title{
EXAMPLE OF POSITIONING INTERMODAL TERMINALS ON INLAND WATERWAYS
}

\begin{abstract}
Positioning of intermodal terminals is of key importance since it affects the very investment into the terminal, ecological, physical issues and the costs of the operation of individual terminals. Detailed analysis has to be performed by decision-making regarding the siting of intermodal terminals. The work analyzes the relevant criteria necessary for the siting of intermodal terminals. The problem of the proposed research is the structure of intermodal systems in the Republic of Croatia with the case study of inland waterways. The research and the study of the characteristics of intermodal terminals network on inland waterways should result in a concept of system reorganization, i.e. terminal planning methodology. By analysing relevant indicators according to the existing facts, and by using scientific methods and methodologies, the relevant criteria necessary to define the position and categories of intermodal terminals on inland waterways in the Republic of Croatia have been defined and evaluated on the examples of Sisak, Osijek, Vukovar and Slavonski Brod.
\end{abstract}

\section{KEY WORDS}

intermodal terminal, intermodal transport, location criteria, inland waterways

\section{INTRODUCTION}

In the area of intermodal transport in Europe and the world, a large number of projects and studies have been carried out, both at international and national level. The means from the programs such as the Fourth, Fifth and Sixth Frame Program of the European Union1, Marco Polo2, INTERREG III3, CARDS4, etc. are used to finance numerous projects regarding transport and intermodality, in the majority of cases based on terminal infrastructure, analysis of cargo flows as well as the network of intermodal terminals in the EU region.

Since the terminal is the central part of the entire intermodal transport chain, in order to identify relevant indicators of the quality and performance, the work analyzes the important processes at terminals, and identifies the main problems and bottlenecks of the process and the operation at terminals. Still, the time losses and high costs do not refer only to the processes at terminals. Attention needs to be directed to the entire intermodal chain. The integration of all the participants in intermodal transport by using information systems and communication technologies (carriers, logistic service providers, rail operators, intermodal operators, terminal operators, forwarding agents, agents, shippers, etc.) makes the integration of various processes even more complex.

This has been implemented in accordance with the organizational, operative and infrastructural problems that affect the quality and success of the terminal operation and the entire intermodal transport. This paper recognizes the main barriers to the terminal operation:

- organizational problems: inadequate form of terminal organization, differences between operative concept of rail transport and the terminal concept, absence of cooperation between different intermodal transport stakeholders;

- problems of management and operative problems: limited working hours of the terminal, absence or poor management of arriving trucks, inefficient internal administrative processes, insufficient safety management systems, low awareness of the terminal operator regarding environmental issues, problems in communication and lack of efficiency, poor control of containers at arrival, insufficient information flow in case of delay, poor control of operations in real time;

- infrastructural problems: shortage of storage space, lack of packaging space, insufficient capacity of crane / manipulation, incompatible transport means / loading units / terminal equipment, poor rail connections with the terminal, failures and equipment malfunctions, insufficient equipment and inadequate procedures for dangerous cargo handling, etc. 
The purpose of research is to analyze the complexity and the problems of intermodal system, i. e. the location of intermodal terminals, their elements and the interaction of the subsystem according to the following criteria: physical, technical, technological, and organizational, all for the purpose of identifying relevant criteria necessary to locate the network of intermodal terminals on inland waterways.

\section{TECHNOLOGICAL ELEMENTS OF PLANNING INTERMODAL TERMINALS}

Several different criteria affect the site selection of the intermodal terminal. The most important criteria are the criteria of cargo flows, technical, technological, location and organizational criteria. The physical and technological characteristics of intermodal terminals depend on several factors which are used to classify the terminals according to [1]:

- type of intermodal units (transport technologies and the structure of intermodal units affect the generation of different forms of intermodal transport);

- position in the transport chain;

- connections to other transport branches;

- functions at the terminal;

- area of coverage;

- role of container transport, etc.

The location of terminals depends on the number of users who will use a certain terminal. The structure and characteristics of the flows determine the type of intermodal terminal and affect the very site selection. Due to their specific characteristics the technologies of the transport chains of container terminal, Ro-Ro terminals, huckepack terminals, also affect the site selection. The technology requires a certain infrastructure, facilities and superstructure.

The characteristics of an efficient intermodal terminal include [2]: location, access to road and rail routes, accompanying servicing activities and technical equipment. The terminals located close to urban areas need to have characteristics of logistic distribution centres. The modifications of the existing terminals are reflected in their technical, technological and environmental possibilities. Transport characteristics have an important influence on the site selection of intermodal terminals. Apart from a good location, also the connection to the European traffic corridor network is important. Economically looking, intermodal terminal on a transport corridor has the development priority. The ecological and climatic actors also influence the site selection. Especially in case of dangerous cargo, the terminal has to be located at a certain distance away from the densely populated ur- ban centres. Legal regulations approve or prohibit the land usage for the terminal development. The economic factor plays an important role in terminal selection since the presence of big industrial enterprises in the environment of potential intermodal terminals can have a crucial and incentive influence on their development. The catchment areas of the terminal are determined by the number, structure and location of logistic users and the accompanying services provided by the intermodal terminal. The factors that affect the catchment area definition include [3]:

1. structure of services at the terminal;

2. users of terminal services;

3. structure of traffic flows;

4. traffic corridors;

5. geo-traffic location of the place in which the terminal is accommodated;

6. traffic connections of terminals with the users;

7. status of the terminal in the network (local, regional, national).

The catchment area, geographic position, transport corridors and traffic flows classify the terminals into four categories: global, international, national and local; whereas physical possibilities for the construction of a terminal refer to its micro and macro environment.

Some of the criteria for the decision-making in planning terminal site selection are divided according to [4]:

a) analysis of the technical feasibility of the terminal (infrastructure, transport equipment...)

For successful introduction and implementation of innovations in the area of terminal organization and technology a number of factors are considered. For the innovations to be sustainable their interoperability with the conventional technologies is important. Therefore, the following has to be determined:

- used intermodal transport units (containers, semi-trailers, exchangeable truck cases, etc.);

- transport equipment (wagons, trucks, container ships);

- connection of potential new terminals into the existing infrastructure network;

- implementation of the regulations - harmonization of the acts and regulations;

- need to take over the cargo transport liability in the entire transport chain and improvement of the existing personnel;

- characteristics of terminal environment.

Up to now, about USD30 billion have been invested into ISO containers, as well as 30 billion in cellular ships that transport them [6]. There is the need to implement into new IT technologies at the terminal, in the promotion of standardization of units (electronic certificates ISO 18185 at the terminal are understood 
as the standards that are used to measure the status of container input on the market), interoperability (standardization of interoperability refers to: equipment and information). This approach will provide all the subjects in the logistic chain with efficient terminal services) as well as the terminal design.

b) economic analysis (costs of investments and depreciation, costs of operation during construction, new costs of operation, time of return on investments, return on investment and revenues, subsidies);

c) requirements for activities (opening to the market and the users).

\section{CASE STUDY "INLAND WATERWAY TERMINAL"}

By studying the problem of the operation of the terminal on inland waterways the following criteria have been highlighted as the important ones: cargo flows, physical criterion, technical and technological and organizational criteria. Cargo flows represent the result of the action and existence of traffic, economic, and other connections between various economic and urban centres or regions, and are characterized by the volume, direction and structure. The extent of the cargo transport depends on the capacity and the production structures of export and import requirements. The volume of cargo that can be expected on individual terminal is very important for the development of a regional terminal. This depends on the function developed by the terminal, catchment area of the terminal, and, naturally, on the attractiveness of a certain location [5]. The existing cargo flows, the potential cargo flows, the economic sector and the independence of the season have been highlighted as the subcriteria of cargo flows. The physical criterion includes the following subcriteria: distance from industrial zones, distance from sea and river ports, distance from airports, distance from transport and rail companies, size of the area and the possibility of expansion.

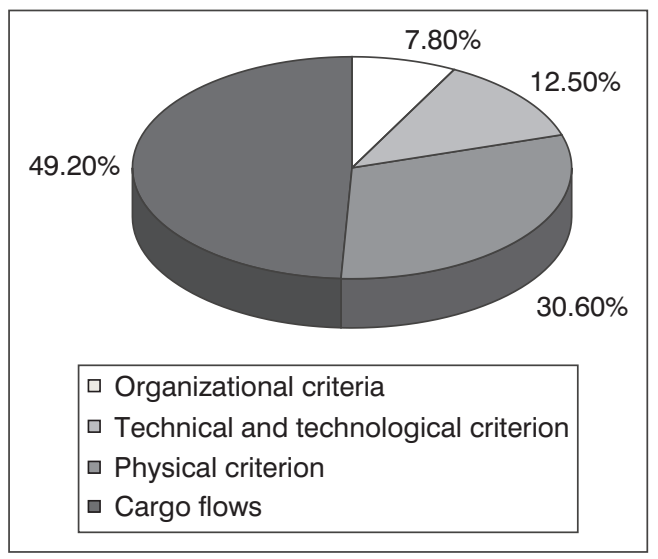

Figure 1 - Criteria priorities
The technical and technological criterion includes the equipment of the terminal, connection with TEN (Trans European Network) corridors, connection with motorways, connection with rail network, connection with inland waterways, connection with seaports and connection with airports. These technical and technological subcriteria enable an analysis and evaluation of the present locations of intermodal terminals on inland waterways [6].

The organizational subcriteria include: the existence of development strategies, human resources, IT support, new protective measures and new safety measures.

In evaluation, the AHP model (Analytical Hierarchy Process) was used, which is based on the analysis of the problems into a hierarchical structure in order to facilitate the perception of the overall problem and to increase the consistency of evaluating the elements. The analytical hierarchy process is a very applicable method of solving complex problems with several alternatives and decision-making criteria. The multi-criteria decision-making model is based on the optimization of the function of objective on the set of possible solutions.

The process enables the decision-makers to set the priorities and to make decisions for the case when it is necessary to take into consideration both quantitative and qualitative characteristics. The method represents a structural approach that allows unification of the logics and intuition in the decision-making procedure. It is based on three basic principles:

- forming of hierarchical structure of the considered problem;

- defining of priorities, and

- logic consistency.

In the selection of subcriteria, several sources from actual studies have been analyzed [6]. Based on the mentioned literature relevant subcriteria have been selected. Based on this analysis as well as the method of survey carried out among transport experts (road, rail, water and air transport), the following relevant subcriteria for their evaluation were selected.

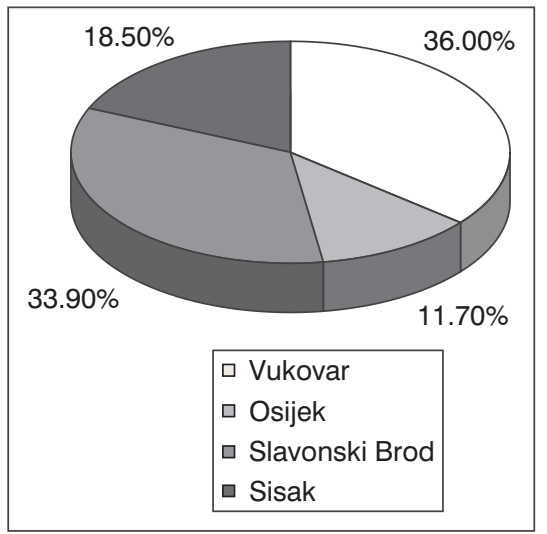

Figure 2 - The results for the alternatives 


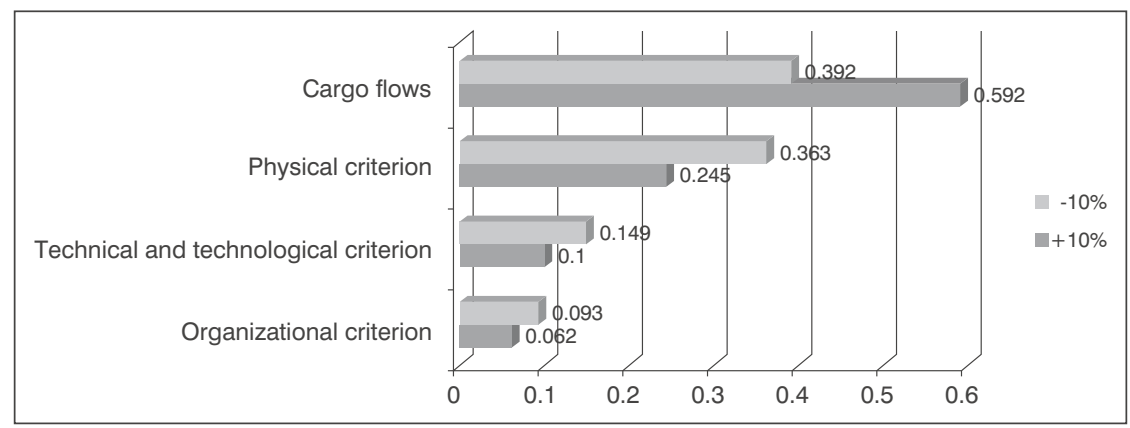

Figure 3 - The results for the criteria with reduction / increase in the significance of share of cargo flows of $10 \%$

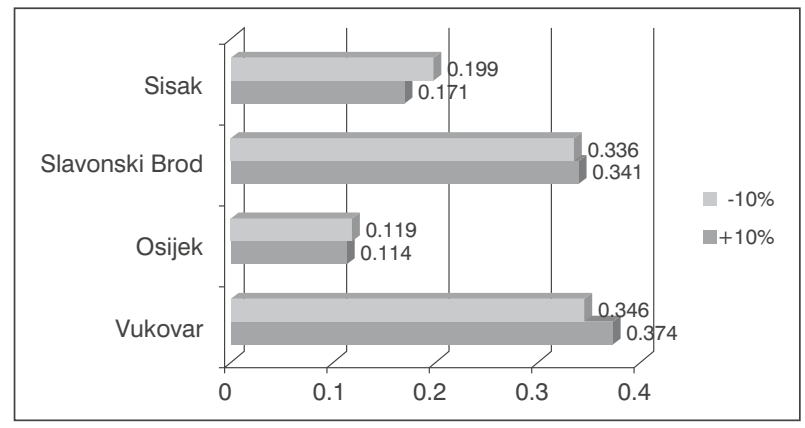

Figure 4 - The results for the alternatives with reduction / increase in the significance of the share of cargo flows of $10 \%$

The evaluation of the main criteria has resulted in the following conclusion: the most important criterion in the site selection of the intermodal terminal on inland waterways is the criterion of cargo flows (49.2 per cent), followed by the physical criterion (30.6 per cent), technical and technological criterion (12.5 per cent) and the least importance lies on the organizational criterion (7.8 per cent) (Figure 1).

Two precondition criteria have been defined: legal and ecological. These have not been used in modelling since the very compliance with them is a precondition in itself [6].

The following Scheme shows the criteria structure for the realization of the objective - the selection of the potential site of the port on inland waterways - the intermodal terminal. Four potential locations have been taken into consideration: Sisak, Slavonski Bord, Osijek and Vukovar.

The research results for the total criteria according to alternatives (potential locations) indicate $36.0 \%$ for the port of Vukovar, 33.9\% for the port of Slavonski Brod, $18.5 \%$ for the port of Sisak and $11.7 \%$ for the port of Osijek (Figure 2).

\subsection{Analysis of the "cargo flows" criterion}

When speaking about the cargo flows criterion of the ports on the inland waterways - intermodal terminals, the highest importance for the site determination lies on the potential cargo flows, because the current cargo flows directed to the ports on inland waterways are not specially expressed in any of the river ports (the priority is expressed in the port of Vukovar, partly in the port of Slavonski Brod and a potential priority in the port of Sisak because of the vicinity of Zagreb). Possible cargo flows, therefore, have great potential of generating port activities and in defining intermodal terminals. The existing cargo flows have a somewhat lower significance, followed by economic sector and independence on the season.

The sensitivity analysis with the increase and reduction of the share of cargo flows by $10 \%$ has shown that the obtained values do not change, i. e. when the cargo flows criterion is analyzed, Vukovar continues to have the priority, as well as Slavonski Brod (Figure 3.4).

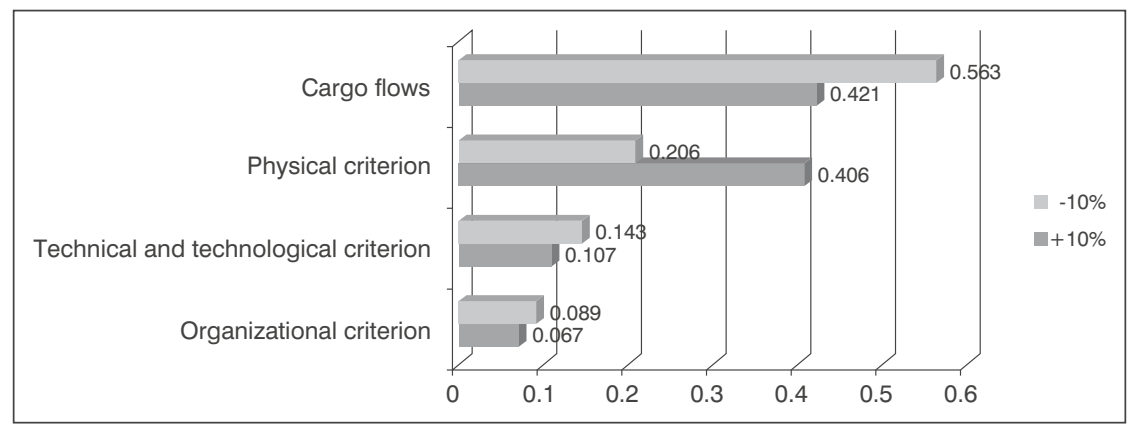

Figure 5 - Results for criteria with the reduction / increase in the significance of the physical criterion of $10 \%$ 


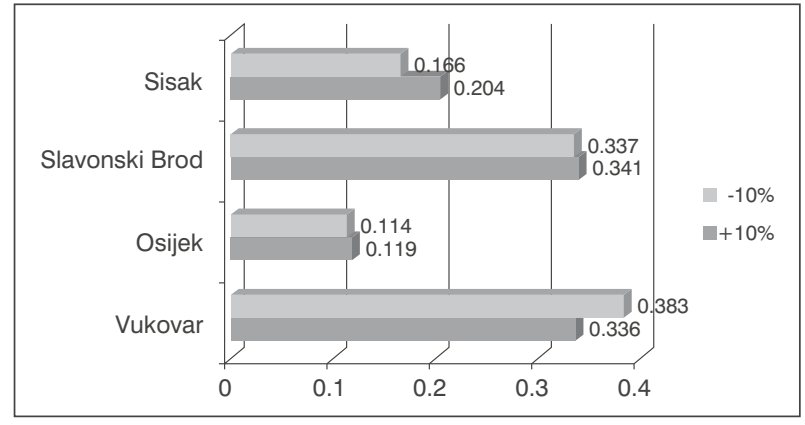

Figure 6 - Results for alternatives with reduction / increase of the significance of the physical criterion of $10 \%$

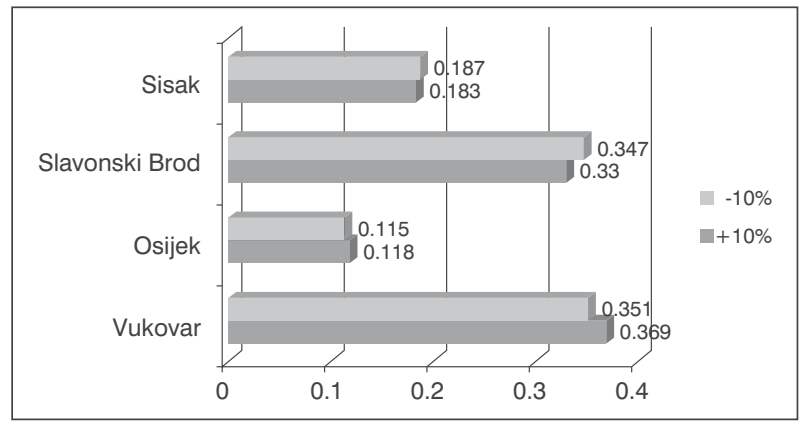

Figure 8 - Results for alternatives with reduction / increase in the significance of technical and technological criterion of $10 \%$

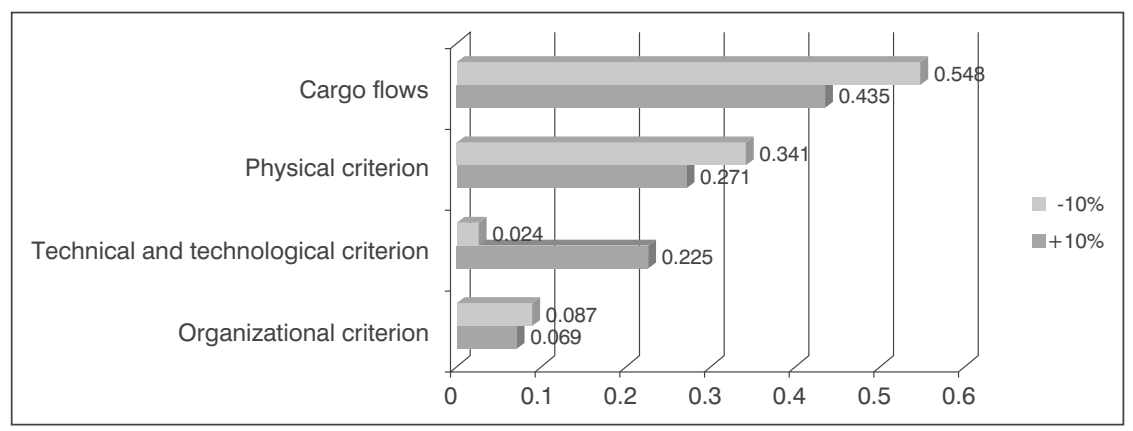

Figure 7 - Results for alternatives with reduction / increase in the significance of the technical and technological criterion of $10 \%$

\subsection{Analysis of the "physical criterion"}

When speaking about the physical criterion then the subcriterion of the possibility of expansion has the highest significance, which is especially expressed in the port of Slavonski Brod. The following subcriteria according to priorities include the size of the area and the distance from the industrial zones. According to the principles of establishing the intermodal transport the next criterion is the distance from the rail companies i. e. from the rail transport infrastructure. Considering the physical criterion, the distance from the airports has been defined by the expertise as the least important subcriterion - factor.

The sensitivity analysis with the increase and reduction of the share of significance of the physical criterion of $10 \%$ has shown that the obtained values do not change, i. e. that when the physical criterion is analyzed, Vukovar continues to have the priority as well as Slavonski Brod, then Sisak and finally Osijek (Figures 5 and 6).

\subsection{Analysis of "technical and technological criterion"}

When speaking of the technical and technological criterion the most important is the subcriterion of the connection with TEN-T network, i. e. TEN-T corridors, the next important is the connection with inland waterways, rail traffic infrastructure and the connection with the seaports. In accordance with the characteristics of this group of intermodal terminals - ports on inland waterways that are connected with other ports by the waterway and with the initiative of constructing the Multi-purpose Danube-Sava Canal, the Croatian river ports have great potential of being connected in the network of the European waterways.

The sensitivity analysis with the increase and reduction of the share of the technical and technological criterion of $10 \%$ has shown that the obtained values do not change, i. e. when the technical - technological criterion is analyzed, Vukovar has the priority, the same as in the first evaluation, Slavonski Brod and Sisak as well (Figures 7 and 8).

\subsection{Analysis of "organizational criterion"}

When speaking of organizational criterion then the highest importance belongs to the existence of the development strategy. This aspect represents a big competitive advantage of the port of Slavonski Brod and the port of Vukovar, and a great drawback of the other two river ports. The human resources represent the next important subcriterion - the moment of the river port development and the setting up of the intermodal terminal. In accordance with the development strategy, there is also the human resources management, i. e. the development, education and training. 


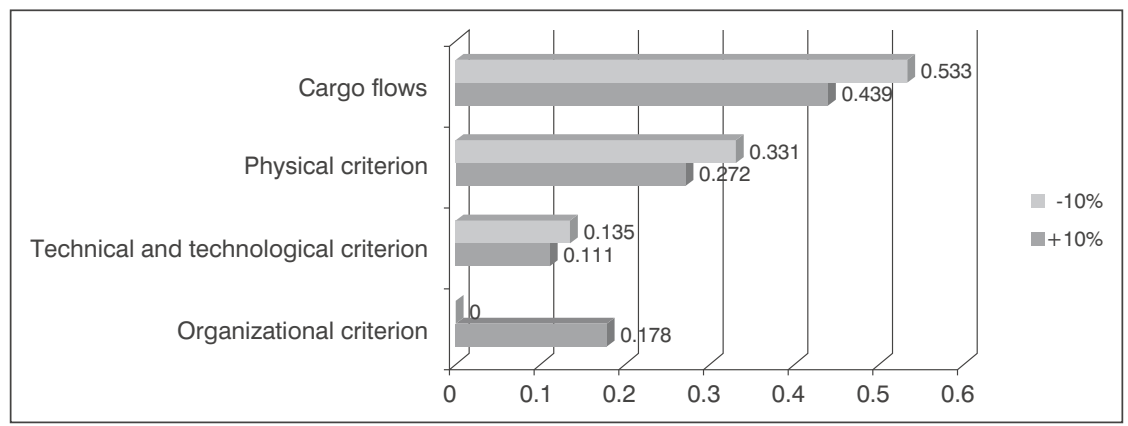

Figure 9 - Results for alternatives with reduction/increase in the significance of organizational criterion of $7.8 / 10 \%$

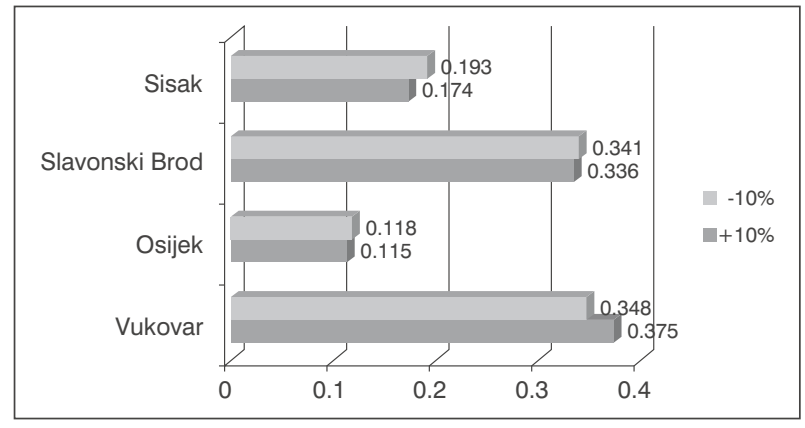

Figure 10 - Results for alternatives with reduction / increase in the significance of organizational criterion of $7.8 / 10 \%$

The sensitivity analysis with the increase and reduction in the share of organizational criterion of $10 \%$ has shown that the obtained values do not change, i. e. when the organizational criterion is analyzed, Vukovar still has the priority as well as Slavonski Brod (Figures 9 and 10).

In further research using multi-criteria decision-making the sensitivity analysis has been performed, i. e. the significances of criteria and subcriteria have been studied in the cases of reduction and increase in the significance of single criteria by $10 \%$. The amount of $10 \%$ represents the realistically possible increase i. e. reduction in the significance caused by the development of the traffic infrastructure, industry and economy in the Republic of Croatia and its environment.

\section{CONCLUSION}

The most important criterion for the site selection of intermodal terminal on inland waterways is the criterion of cargo flows (49.2\%), followed by the physical criterion (30.6\%), technical-technological criterion $(12.5 \%)$ and the least importance belongs to the organizational criterion $(7.8 \%)$. The studies lead to the conclusion that the cargo criterion according to the total volume, cargo structure and direction of movement have been imposed and represent the basis in locating and site selection of intermodal terminals on inland waterways. The priority of the cargo flows criterion has been expressed in the port of Vukovar, whereas in the physical criterion the highest importance among the ports belongs to the port of Slavonski Brod. The river ports analysed in the paper have high potential of being connected into the network of the European waterways, thus also fulfilling the main subcriterion - the technical-technological criterion. The organizational criterion is fully met by the ports of Slavonski Brod and Vukovar, since the existence of a development strategy carries the highest priority. In the analysis of the physical criterion the highest importance belongs to the subcriterion of the port expansion possibility, generated by the increase in the cargo flows on inland waterways in the Republic of Croatia.

The conclusions of the sensitivity analysis of the criteria for the setting up of intermodal terminals ports on the inland waterways are the following:

- an increase in the significance of each cargo flow, technical-technological criterion and the organizational criterion in the amount of $10 \%$ do not change the results and the defined potential of the sites for the setting up of intermodal terminals in relation to the initial results;

- an increase in the significance of the physical criterion in the amount of $10 \%$ places the potential of the port of Slavonski Brod as an intermodal terminal on the first place;

- the reduction in the significance of the criterion of cargo flows, physical criterion and the technical-technological criterion in the amount of $10 \%$ do not change the results and the potential of locations for the setting up of intermodal terminal in relation to the initial results, as well as the reduction in the significance of the organizational criterion in the amount of $7.8 \%$ does not change the results and the potential of the location for setting up intermodal terminals in relation to the initial results.

The defined multi-criteria decision-making model in intermodal terminal siting allows the decision makers to make the assessment even before these are implemented in practice. In order to unify all the relevant segments in the sustainable development of 
intermodal transport the defined model represents the scientific methodology and an efficient method for the assessment of potential solutions of intermodal terminals on inland waterways.

Dr. sc. NIKOLINA BRNJAC

E-mail: brnjac@fpz.hr

IVANA ĆAVAR, dipl. ing.

E-mail: ivana.cavar@fpz.hr

Sveučilište u Zagrebu, Fakultet prometnih znanosti

Vukelićeva 4, 10000 Zagreb, Republika Hrvatska

\section{SAŽETAK}

\section{PRIMJER POZICIONIRANJA INTERMODALNIH TERMINALA NA UNUTARNJIM PLOVNIM PUTOVIMA}

Pozicioniranje intermodalnih terminala od ključne je važnosti budući da ono utječe na samu investiciju u terminal, ekološke, prostorne probleme $i$ na troškove rada pojedinog terminala. Postupkom donošenja odluke u vezi s lokacijom intermodalnih terminala mora se provesti detaljna analiza. $U$ radu se analiziraju relevantni kriteriji potrebni za lociranje intermodalnih terminala. Problem predloženog istraživanja je struktura intermodalnih sustava u RH s primjerom na unutarnjim plovnim putovima. Istraživanje i izučavanje obilježja mreža intermodalnih terminala na unutarnjim plovnim putovima treba rezultirati konceptom reorganizacije sustava, odnosno metododologijom planiranja terminala. Analizom relevantnih indikatora sukladno postojećim činjenicama, korištenjem znanstvenih metoda $i$ metodologija definirani su $i$ vrednovani relevantni kriteriji potrebni za definiranje položaja $i$ kategorije intermodalnih terminala na unutarnjim plovnim putovima u RH na primjeru Siska, Osijeka, Vukovara i Slavonskog Broda.

\section{KLJUČNE RIJEČI}

intermodalni terminal, intermodalni prijevoz, kriteriji lociranja, unutarnji plovni putovi

\section{LITERATURE}

[1] Huub Vrenken, Cathy Macharis, Peter Wolters: Intermodal transport in Europe, EIA, Brussels, 2005

[2] "INTERMODA" Project Freight Terminals: An Analysis of the Terminal Market, Transportation Planning and Technology, OPA, 23.

[3] Brnjac, N., Jolić, N., Bukljaš, M.: Prostorne i tehničko-tehnološke mogućnosti za izgradnju intermodalnih terminala - Case study Croatia, ZIRP 2008.

[4] Recommendations for policy and research activities: Phase II, Deliverable 4.1, EUTPII, Thematic Network on Freight Transfer Points and Terminals, European Community

[5] Jenček, P., Twrdy, E.: Development of Regional Transport Logistics Terminal - Transport Logistics Approach, Promet - Traffic - Traffico, Vol. 20, 2008.

[6] INTERMODARH, Strategija razvoja intermodalnog transporta $i$ mreže intermodalnih terminala $u \mathrm{RH}$, Faculty of Transport and Traffic Sciences, 2008

[7] White Paper, European Transport Policy for 2010: Time to Decide European Commission, Brussels, 2001.

[8] Study on Freight Integrators to the Commission of the European Communities Final Report, 16/9/2003

[9] IMONODE, Efficient integration of cargo Transport modes \& Nodes in Cadses area, INTEREG III B, Deliverable 4.

[10] Freight Market Structure and Requirements for Intermodal Shifts, TREN/06/FP6TR/S07.60148, Integrated Project (IP), Sustainable surface transport - Rebalancing and integrating different transport modes, Deliverable 11.1, 'Freight Market Structure and Requirements for Intermodal Shifts', European Commission within the Sixth Framework Programme (2002-2006) 